\title{
12
}

\section{FILLING THE BLANKS. POLITICAL PARTIES, INTEREST GROUPS, AND REPRESENTATION OF CIVIL SOCIETY}

\section{Paweł Kamiński}

\section{Introduction}

While political parties have been at the center of scholarly attention in recent decades, research on interest groups has gained traction only lately. Besides a few notable exceptions (Thomas, 2001; Witko, 2009; Allern, 2010; Allern \& Bale, 2012, 2017; Otjes \& Rasmussen, 2017), we lack a systematic analysis of interactions between these two actors, not to mention whether interest groups are replacing political parties in representing certain groups of citizens. For example, as Lefkofridi et al. (2014) have suggested, some groups of voters are less represented by parties than others. Furthermore, scholars have also suggested that political parties are increasingly interested in the cartelization of politics, where they are more inclined to penetrate the state than to fight for voters and members (Katz \& Mair, 1995). Are interest groups at least partially able to compensate for the absence of political parties?

I investigate whether both political parties and interest groups carry the same type of representational biases or whether the latter could make up for parties' shifts towards certain types of electorate. To empirically verify this assumption, I map groups' and parties' positions on Gal-Tan and economic matters. The GalTan dimension (green, alternative, libertarian versus traditional, authoritarian, nationalist) has become increasingly popular among scholars investigating party stances on Europeanization (Hooghe et al., 2002). Regarding economic matters, where parties are set apart by different points of view on economic redistribution, welfare, and government regulation of the economy, it allows researchers to map political parties on four ideological quadrants (left-tan, right-tan, left-gal, and right-gal) (Vachudova \& Hooghe, 2009). As party competition has recently been dictated not only by the left-right division, Gal-Tan adds multidimensionality regarding the socio-cultural dimension. 
I analyze six countries - three from CEE (Poland, Slovenia, and Lithuania) and three from Western Europe (Belgium, Sweden, and the Netherlands). Both regions have had diverging trajectories of party politics (Vachudova \& Hooghe, 2009). The collapse of communism in the East, Europeanization, and, last but not the least, the lack of societal embeddedness, created completely different dynamics for the institutionalization of political parties and civil societies.

There are various definitions and interpretations of what an interest group is (for discussion, see Beyers et al., 2008). I follow the definition of interest groups provided by Thomas (2001, p. 7): "An interest group is an association of individuals or organizations, usually formally organized, that attempts to influence public policy". By contrast, a political party is "any political group that presents at elections, and is capable of placing through elections, candidates for public office" (Sartori, 1976, p. 64).

\section{Cartelization}

As argued in a seminal article by Katz and Mair (1995), in contrast to previous time periods when other organizational models (elite caucus or cadre party, mass party, catch-all party) were dominant, the cartel party emerged in the late 20th century. Contrary to its predecessors, the cartel party is less interested in gaining people's support than exploiting the resources of the state and position itself within it. Parties, as Katz and Mair have argued, function therefore as cartels, trying to limit the emergence of competition and ensure that the party in public office has the upper hand over the party on the ground and the party central office (Krašovec \& Haughton, 2011).

The research on cartelization has primarily been focused on western democracies, with a few notable examples (Yishai, 1998; Szczerbiak, 2001; Sikk, 2003; van Biezen, 2003; Bolleyer, 2009). Where does it leave us with CEE countries? As Katz and Mair (2012) point out, political parties in post-communist democracies share many problems with those in old democracies, but contrary to them, they do not have the institutional advantage of having functioned for several decades. Moreover, it has been debated that parties in CEE might immediately embrace the cartel model, according to which the relationship with interest groups and, in general, civil society is loose (Szczerbiak, 2001; Sikk, 2003; Krašovec \& Haughton, 2011). There have also been concerns that civil society itself is so weak and fragmented that it would not channel societal interests into organized forms (Dobbins \& Riedel, 2018). Katz and Mair (2012) even argued that instead of arduously building relationships with civil society, political parties could take a shortcut, build their own organizations, and establish permanent dominance over them. They also contended that all the previous models of party competition have focused on their relationship with voters, while their relationship with the state should be treated as equally important.

First, after the Second World War, parties became less and less agents of civil society acting in the interests of their constituency and penetrating the state 
on their behalf. Instead, they became agents of the state themselves (Katz \& Mair, 1995, p. 18). Thus, cartel parties have become detached from their traditional constituencies even more as their dependence on state subsidies has grown substantially. Such parties penetrate and operate within the state, are highly professionalized, weakly anchored in society, and use their privileged financial positions - above political divisions - to limit the likelihood of new entities entering the system (Mair, 1997; van Biezen et al., 2012; Fraussen \& Halpin, 2018).

Secondly, Katz and Mair distinguished three ideal types of a modern political party - (1) party in office (in parliament or in government), (2) party on the ground (activists and local branches), and finally (3) party's central office (party leaders). Particularly remarkable for Katz and Mair is that the party in office has dominated the other two types. They argue that "as the party in public office gains ascendancy within the party as a whole, its particular interests will be treated as being the interests of the party writ large" (Katz \& Mair, 2009, p. 756).

I argue that political parties in Europe are generally drifting towards the cartel mode. As the proliferation of new parties entering the system decreases, the ideological saturation of the party scene could be reduced as well (for a discussion about party funding, see Häusermann \& Geering, 2011; Casal Bértoa \& Spirova, 2019). Political parties are becoming more interested in achieving electoral and financing thresholds. Therefore, they could strategically turn away from political positions that do not guarantee staying in the (cartel) system. Moreover, ties with parties' collateral organizations like trade unions or agrarian associations have been more relaxed lately. Parties used to rely on such grassroot organizations to mobilize support and gain new members. With the emergence of the catchall model, political parties attempted to appeal to broader audiences. In consequence, parties took a more independent position on interest groups, trying to free themselves from constraining relationships (Katz \& Mair, 1995; van Biezen et al., 2012; Allern \& Bale, 2012).

\section{Interest groups as a second go-to option}

As a consequence, the "decline of parties" and party democracy (Dalton et al., 2011) paint a different picture for citizens. Parties may no longer be interested in representing a broad spectrum of voters and this may create gaps in representational relationship. Voters may no longer feel represented and may show antiparty sentiment as well (Poguntke, 1996). Subsequently, they could look for alternatives and turn to interest groups as another form of preference aggregation. As Borang and her colleagues have argued, interest groups do not necessarily carry the same ideological history, pre-existing voting constituencies, or organizational structures that make it difficult for political parties to reach voters above socio-economic cleavages in societies (Borang et al., 2017).

Furthermore, it has been debated elsewhere that it is actually plausible to address interest groups as "political organizations" in the same manner as political parties (Fraussen \& Halpin, 2018). Heaney (2010, p. 568) has even argued that 
groups and parties are "intricately and inextricably linked to one another". Furthermore, Fraussen and Halpin hypothesized that

given the high level of similarities, not only in organizational form but also in the external challenges that they face, studying political parties and interest organizations in tandem can deliver more insights into the nature and evolution of these organizations.

(2018, p. 26)

More generally, interest organizations are seen here as entities channeling policy preferences and bringing them to the political arena in the form of agenda setting, and simultaneously also influencing policy processes, becoming intermediaries - or transmission belts - between the public and the state (Easton, 1971; Truman, 1993).

One important difference between parties and interest organizations is that the latter do not compete in elections. In order to influence policy-making processes, they need to interact with political parties, parliamentary committees, or governmental agencies. Keeping in mind this important difference, some scholars have observed many similarities between interest organizations and political parties (Fraussen \& Halpin, 2018).

According to Burstein and Linton (2002, pp. 381-382), either parties or interest organizations “define public problems, propose solutions, aggregate citizen's policy preferences, mobilize voters, make demands of elected officials, communicate information about government action to their supporters and the larger public, and make relatively coherent legislative action possible". Allern and Bale (2012) have highlighted the role of parties and groups in aggregating the public's interests into collective demands and seeking to influence the form and content of public policy. By contrast, Fraussen and Halpin (2018) have discussed the possibility that interest groups might have followed the same path as political parties by becoming very professionalized, managed from above and having little to do with local constituencies apart from collecting membership fees.

According to Theda Skocpol, older groups are more likely to undergo the process of professionalization and centralization. These organizations are often devoid of membership involvement and usually focused on single issues, resulting in "diminished democracy", whereby their civic and integrative dimension is lost (Skocpol, 2003).

Organized interests - grassroots movements, various professional associations, or cause groups - allow citizens to pursue shared objectives in an institutional way (Putnam, 1995). A high density of interest organizations along regular channels of communication between citizens and interests and their governments is seen to be crucial for the emergence of liberal democracy (Putnam, 1993; Elster et al., 1998). For instance, when interest groups and the public are on the same page in terms of policy preferences, the likelihood of adoption of a jointly preferred law increases (Gilens, 2012). Groups' activities in certain policy areas have also had a positive impact on bringing decision-makers' attention to issues (Rasmussen 
et al., 2014; Berkhout et al., 2020; Bevan \& Rasmussen, 2020). In this sense, the chapter bridges research on social movement organizations (SMOs), civil society organizations (CSOs), non-governmental organizations (NGOs), and, obviously, interest organizations. Beyers et al. (2008) bitterly remark that scholars of former groups can go to great lengths to avoid the "interest group" label, often seen as something negative, elitist, and undemocratic. However, interest groups research sees them as politically and democratically useful, and, in fact, analyzes the same phenomenon as research on SMOs or NGOs, "as [interest groups] evolve over time, incorporate multiple purposes and structural features from all three prevailing forms" (Hasenfeld \& Gidron, 2005, p. 98). Finally, one could say that "NGOs" is a "hurrah" word for the "boo" word "interest group", as Grant argues (2001).

Nonetheless, our knowledge about interest groups as a potential substitute for political parties is very scarce and limited to Western Europe and the United States. We know very little about how political parties and interest groups behave in the post-communist environment. It should be also noted here that the development of organized interests and political parties has had a different dynamics than in Western Europe (Mair, 1997; Kitschelt et al., 1999; Enyedi, 2006). The departure point for democracy was not a century-long overlapping process, but rather an unexpected collapse of communism. In consequence, the transition was three-fold, with simultaneous creation of new political, economic, and constitutional systems, and in some cases also new states (Offe \& Adler, 1991; Bunce, 1995; Bohle \& Greskovits, 2012; see Labanino \& Dobbins in this volume). A half century of authoritarianism destroyed traditional parties, weakened classes and interests, and undermined the social trust necessary to kick-start social participation (Crawford \& Lijphart, 1995). Moreover, when this particularly relates to the Gal-Tan dimension, the whole region underwent the process of Europeanization in the form of EU accession talks, which became an overriding national priority (Vachudova \& Hooghe, 2009). As Hooghe et al. (2002) suggested, the Gal-Tan is more useful here in predicting stances towards EU than the standard left-right division.

\section{Data sources and methodology}

The countries included in this study are Belgium, the Netherlands, Sweden, Lithuania, Poland, and Slovenia. By including three "old" West European democracies with newcomers from CEE, we are able to compare how interest groups position themselves in different environments and find out whether there are any substantial differences between East and West.

Each country is different, not only in size and population, but also the state of civil society, institutional representation of its interests as well as the structure of party systems and political parties. Furthermore, we can expect the institutional nature of an interest group system to play a role here. Here, one discerns two dominant systems: neo-corporatism and pluralism (see Chapter 5 in this volume). This distinction refers to variation regarding "the extent of state autonomy, the 
degree of societal organization, the variety, legitimacy and degree of interest group participation" (Eising, 2008; Fraussen \& Beyers, 2016). A pluralist system is mainly fragmented and shaped by competition among interest groups for policymakers' attention. By contrast, in neo-corporatist settings, access is highly organized, usually granted to few privileged groups (Binderkrantz \& Christiansen, 2015; Christiansen et al., 2018). As Western European countries and Slovenia have been portrayed as neo-corporatist, other CEE countries, including Poland and Lithuania, have had weak organized arrangements with a plethora of actors competing for influence (Hassel, 2008). Taking this into account, the selection of both Eastern and Western European countries differing on a range of other factors (e.g. level of corporatism, party system properties, interest group populations) makes the findings reasonably generalizable within the European context.

In order to measure ideological positions of interest groups and political parties, I use the "Gal-Tan" and economic "left-right" scale. While the economic placement is still crucial for party competition, the former allows us to capture the cultural and post-material dimension of politics (Hooghe et al., 2002; Bornschier, 2010; Rohrschneider \& Whitefield, 2012). The Gal-Tan scale indicates positions involving such issues as gay marriage, abortion, the role of religion, immigration, multiculturalism, and environmentalism (Wheatley \& Mendez, 2019). Furthermore, it has been shown in other studies that Gal-Tan could be very useful in predicting party positions on the above-mentioned matters. The only drawback is that the data comes from 2014 and therefore might not necessarily be up-do-date with current developments on party positions and emergence of new parties (Hanley \& Sikk, 2016) (Table 12.1).

Party positions are measured based on the Chapel Hill Expert Survey 2014 (CHES). The CHES data provide expert evaluations on dozens of issues and it so far has been one of the most popular and reliable sources on party research. CHES treats Gal-Tan as stances on democratic freedoms and rights (Polk et al., 2017, p. 19). "Libertarian" or "postmaterialist" parties favor expanded personal freedoms, for example, access to abortion, active euthanasia, same-sex marriage, or greater democratic participation. "Traditional" or "authoritarian" parties often reject these ideas; they value order, tradition, and stability, and believe that the government should be a firm moral authority on social and cultural issues. Similarly, on the economic left-right scale, "parties want government to play an active role in the economy. Parties on the economic right emphasize a reduced economic role for government: privatization, lower taxes, less regulation, less government spending, and a leaner welfare state" (Polk et al, 2017, p. 18).

Subsequently, the data on interest groups come from Comparative Interest Group Survey (CIGS), a multinational project which investigates dozens of European countries. ${ }^{1}$ Surveys were conducted in 2016 in Slovenia, Lithuania, Belgium, the Netherlands, and Sweden. Poland joined the project between 2017 and 2018. For the purpose of this chapter, we use data from 4,100 interest groups from Poland, Slovenia, and Lithuania - the only three post-communist countries involved in the project - as well as three Western European democracies: 
TABLE 12.1 Political parties included in the analysis

\begin{tabular}{|c|c|c|c|c|}
\hline Country & Party & Vote & Seats & Family $^{\mathrm{a}}$ \\
\hline Lithuania & LSDP & 18.4 & 26.2 & Socialist \\
\hline Lithuania & TS-LKD & 15.1 & 23.4 & Conservative \\
\hline Lithuania & LVZS & 3.9 & .7 & Agrarian/center \\
\hline Lithuania & LLRA & 5.8 & 5.7 & Regionalist \\
\hline Lithuania & $\mathrm{TT}$ & 7.3 & 7.8 & Conservative \\
\hline Lithuania & $\mathrm{DP}$ & 19.8 & 20.6 & Liberal \\
\hline Lithuania & LRLS & 8.6 & 7.1 & Liberal \\
\hline Lithuania & DK & 8.0 & 5 & No family \\
\hline Poland & SLD & 8.19 & 5.9 & Socialist \\
\hline Poland & $\mathrm{PO}$ & 39.2 & 45 & Christian democracy \\
\hline Poland & PiS & 29.9 & 34.1 & Radical right \\
\hline Poland & PSL & 8.4 & 6.1 & Agrarian/center \\
\hline Poland & $\mathrm{RP}$ & 10 & 8.69 & Liberal \\
\hline Poland & KNP & 1.1 & 0 & Conservative \\
\hline Poland & PR & 0.2 & 0 & Conservative \\
\hline Poland & $\mathrm{SP}$ & & & Conservative \\
\hline Slovenia & SDS & 20.7 & 23.3 & Christian democracy \\
\hline Slovenia & SD & 6 & 6.7 & Socialist \\
\hline Slovenia & SLS & 4 & 0 & Regionalist \\
\hline Slovenia & NSI & 5.6 & 5.6 & Conservative \\
\hline Slovenia & DeSUS & 10.2 & 11.1 & Rad right \\
\hline Slovenia & SMC & 34.5 & 40 & Liberal \\
\hline Slovenia & $\mathrm{ZL}$ & 6 & 6.7 & Conservative \\
\hline Slovenia & $\mathrm{ZaAB}$ & 4.4 & 4.4 & Conservative \\
\hline Slovenia & PS & 3 & 0 & Conservative \\
\hline Netherlands & $\mathrm{CDA}$ & 8.5 & 8.69 & No family \\
\hline Netherlands & PvdA & 24.8 & 25.3 & Socialist \\
\hline Netherlands & VVD & 26.6 & 27.3 & Liberal \\
\hline Netherlands & D66 & 8 & 8 & Liberal \\
\hline Netherlands & GL & 2.3 & 2.7 & Green \\
\hline Netherlands & SGP & 2.1 & 2 & Confessional \\
\hline Netherlands & SP & 9.69 & 10 & Rad left \\
\hline Netherlands & $\mathrm{CU}$ & 3.1 & 3.3 & Confessional \\
\hline Netherlands & PVV & 10.1 & 10 & Radical right \\
\hline Netherlands & PvdD & 1.9 & 1.3 & Green \\
\hline Netherlands & 50PLUS & 1.9 & 1.3 & No family \\
\hline Sweden & $\mathrm{V}$ & 5.7 & 6 & Rad left \\
\hline Sweden & SAP & 31 & 32.4 & Socialist \\
\hline Sweden & $\mathrm{C}$ & 6.1 & 6.3 & Agrarian/center \\
\hline Sweden & $\mathrm{FP}$ & 5.4 & 5.4 & Liberal \\
\hline Sweden & M & 23.3 & 24.1 & Conservative \\
\hline Sweden & $\mathrm{KD}$ & 4.6 & 4.6 & Christian democracy \\
\hline Sweden & MP & 6.9 & 7.2 & Green \\
\hline Sweden & $\mathrm{SD}$ & 12.9 & 14 & Radical right \\
\hline Sweden & PIRAT & 0.4 & 0 & No family \\
\hline Sweden & FI & 3.1 & 0 & No family \\
\hline
\end{tabular}




\begin{tabular}{llccl} 
Country & Party & Vote & Seats & Family $^{\mathbf{a}}$ \\
\hline Belgium & PS & 11.7 & 15.3 & Socialist \\
Belgium & SPA & 8.80 & 8.69 & Socialist \\
Belgium & ECOLO & 3.3 & 4 & Green \\
Belgium & Groen & 5.3 & 4 & Green \\
Belgium & MR & 9.6 & 13.3 & Liberal \\
Belgium & VLD & 9.80 & 9.30 & Liberal \\
Belgium & cdH & 5 & 6 & Christian democracy \\
Belgium & CD\&V & 11.6 & 12 & Christian democracy \\
Belgium & N-VA & 20.3 & 22 & Regionalist \\
Belgium & FDF & 1.8 & 1.3 & Regionalist \\
Belgium & VB & 3.7 & 2 & Rad right \\
Belgium & PVDA & 3.7 & 1.3 & Rad left \\
Belgium & PP & 1.5 & 0.7 & Conservative \\
\hline
\end{tabular}

a The typology of political parties according to Chapell Hill Expert Survey, not the author of the chapter. See https://www.chesdata.eu.

Source: CHES 2014.

TABLE 12.2 Types of interest groups and their populations

\begin{tabular}{|c|c|c|c|c|c|c|}
\hline & Belgium & $\begin{array}{l}\text { The } \\
\text { Netherlands }\end{array}$ & Sweden & Lithuania & Poland & Slovenia \\
\hline $\begin{array}{l}\text { Business } \\
\quad \text { associations (1) }\end{array}$ & $0.23(219)$ & $0.16(138)$ & $0.19(192)$ & $0.22(80)$ & $0.29(112)$ & $0.09(41)$ \\
\hline $\begin{array}{l}\text { Professional } \\
\quad \text { associations (2) }\end{array}$ & $0.19(182)$ & $0.17(145)$ & $0.12(185)$ & $0.29(106)$ & $0.05(18)$ & $0.33(147)$ \\
\hline Labour (3) & $0.02(19)$ & $0.01(12)$ & $0.03(43)$ & $0.06(23)$ & $0.03(14)$ & $0.07(34)$ \\
\hline $\begin{array}{l}\text { Identity } \\
\quad \text { organizations (4) }\end{array}$ & $0.15(142)$ & $0.22(192)$ & $0.07(103)$ & $0.14(51)$ & $0.10(39)$ & $0.14(63)$ \\
\hline $\begin{array}{l}\text { Cause } \\
\quad \text { organizations (5) }\end{array}$ & $0.20(196)$ & $0.14(120)$ & $0.46(416)$ & $0.08(32)$ & $0.40(157)$ & $0.08(35)$ \\
\hline $\begin{array}{l}\text { Leisure } \\
\quad \text { associations (6) }\end{array}$ & $0.14(137)$ & $0.13(115)$ & $0.09(144)$ & $0.08(29)$ & $0.03(10)$ & $0.22(98)$ \\
\hline $\begin{array}{l}\text { Associations } \\
\text { of public } \\
\text { authorities (7) }\end{array}$ & $0.04(35)$ & $0.16(141)$ & $0.02(25)$ & $0.05(20)$ & $0.05(20)$ & $0.02(10)$ \\
\hline \multirow[t]{2}{*}{ Rest (8) } & $0.03(29)$ & $0.01(3)$ & $0.02(32)$ & $0.07(26)$ & $0.07(26)$ & $0.02(10)$ \\
\hline & 959 & 866 & 1,111 & 367 & 397 & 438 \\
\hline
\end{tabular}

Belgium, the Netherlands, and Sweden. Table 12.2 provides a typology of surveyed organizations as well as distributions across different countries.

The sampling procedures applied to gather the data differ between different countries, which is normal if we take into account difficulties in accessing the information. The response rate ranged from $27 \%$ for Poland, $36 \%$ for Slovenia, $40 \%$ for Lithuania, 38\% for the Netherlands, $41 \%$ for Belgium, and $42 \%$ for Sweden. 
To measure the economic left-right dimension, interviewees were asked:

Interest organizations and civil society associations have different views on the role of government in economic matters. Some want government to play an active role in the economy, e.g. through taxation, regulation, government spending, or a strong welfare state. Others prefer a reduced economic role for government, e.g. through privatization, lower taxes, less regulation, less government spending, or a leaner welfare state. On a scale from 0 to 10 , where " 0 " means that government should play a much reduced role in the economy and " 10 " means that government should play a very active role in the economy, where would you position your organization on this scale?

Similar to CHES, interest groups were asked about their positions on "personal freedoms":

Interest organizations and civil society associations have different views on personal freedoms and rights. Some support greater personal freedom, e.g. access to abortion, euthanasia, same-sex marriage, or greater democratic participation (libertarian views). Others reject these ideas; they value order, tradition, and stability, and believe that the government should be a firm moral authority on social and cultural issues (traditional views). On a scale of 0 to 10 , where " 0 " is "of no importance" and " 10 " is "of great importance", how important would you say are social, moral, and cultural issues of this kind to your organization in its lobbying and advocacy activities?

The important difference between both survey questionnaires is the fact that while in CIGS "O" indicates that state should play a reduced role in economy, in CHES " 0 " means that parties want government to play an active role in the economy. To synchronize both datasets, I reversed the CHES scale to mirror the CIGS data points. This means that parties and groups placed farthest right on the horizontal axis assume that state should play a key role in the economy (see Table 12.1).

The CIGS project follows a broad definition of interest groups, where the group is an entity standing between the state and the civil society. Its aim is to aggregate and represent the interests (e.g. companies, workers), a cause (e.g. the environment, health, consumers), or some constituency (e.g. refugees, unemployed, poor) (Beyers et al., 2016). Therefore, it allowed us to catch a variety of groups: business associations, employers' associations, citizens groups, trade unions, or third sector organizations.

Below I present a descriptive analysis of Gal-Tan and economic placements of political parties and interest groups. I am particularly interested in whether the latter could occupy spaces left by political parties, or, whether either of them follow suit and strategically place themselves. The positive aspect of such an analysis is that we can spatially map policy preferences, clearly identify patterns, and compare them between certain actors (parties, groups, and citizens). The 
drawbacks we should be aware of are that two-dimensional positioning strips the analysis of the necessary context. Moreover, if used to compare different countries (or cultures) with different experiences, we never know how to understand "traditional", "liberal", or "active role of the state", not to mention language-specific subtleties.

\section{Results}

Figure 12.1 presents the Gal-Tan and economic left-right placement of political parties according to CHES data. As we can see, there are substantial differences between countries. Obviously, in democratic regimes, political parties cannot stray too far away from public opinion and the electorate, meaning that extreme spaces are less populated. However, in the six countries of interest, there are no parties placed in left-tan spaces, with the outermost position around 7.0. Regarding CEE countries, the explanation might lie in the legacy and unpopularity of communism. When the democratic transformation began, parties - especially post-communist ones - were incentivized to abandon left-authoritarian positions and move towards Tan positions. As Vachudova and Hooghe (2009) suggest, EU accession talks and EU membership influenced party politics in such a way that eventually political parties fine-tuned their programs to EU standards. Furthermore, the process of Europeanization, marketization, and course towards neoliberalism could have prevented parties from extreme left-leaning policies (Haughton, 2014; Coman, 2017). As for Western European democracies, the supply and demand dynamics of party systems after the Second World War

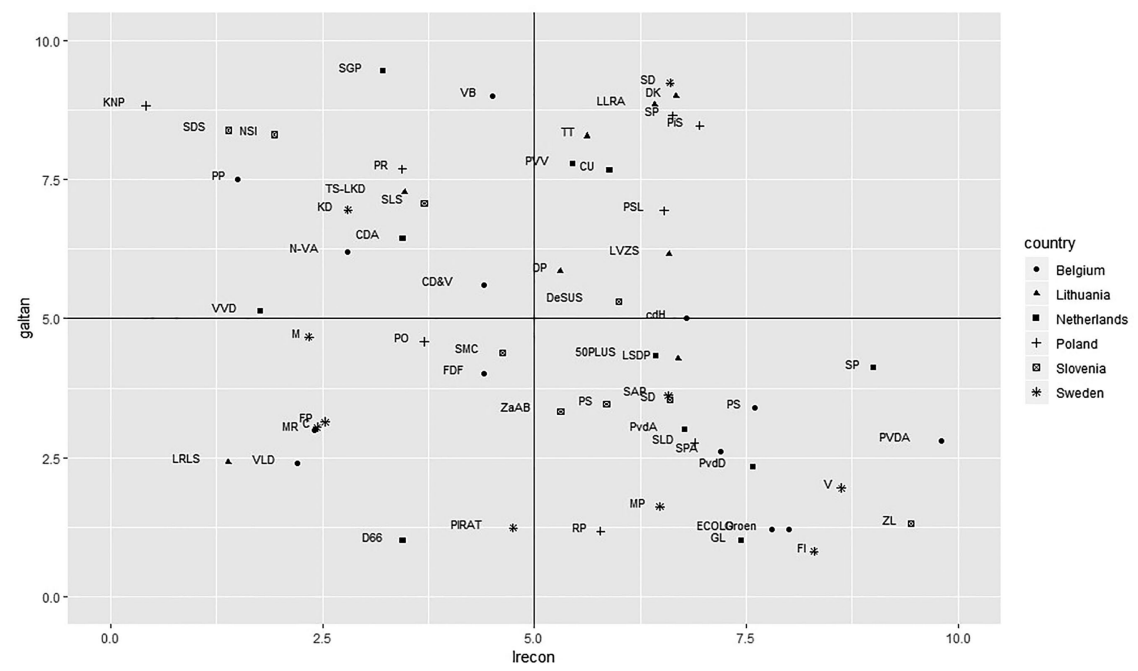

FIGURE 12.1 Gal-Tan and economic left-right placement of political parties. Source: CHES 2014. 
perhaps have never materialized to establish institutional actors representing nationalist, traditional agendas melting with redistributive policies.

Thus, what gap do interest groups fill for political parties? Apart from abandoned outmost spaces in each quadrant, populating vast spaces in tan-economic left would be worthy of further investigation, particularly from a bottom-up perspective. However, it could be safely assumed that as party politics has moved to the 45 degree axis between tan-right and tan-left to presumably seek political gain and moderate voters, it does not mean that these spaces are not populated by interest organizations that are not subjected to verification in elections and are not constrained by adjusting to EU and market policies.

There are some similarities between Lithuanian and Polish political parties, where many have been located around the upper half. Moreover, there is no shortage of parties in the authoritarian half, which might be symptomatic of current events in the region, sometimes referred to as the illiberal turn or democratic backsliding (Sata \& Karolewski, 2020). Moreover, only three parties are located in the right-green-alternative-libertarian quadrant.

Now, we move to self-placement of interest organizations. Similar to party positioning, Lithuania and Poland appear to have more in common with each other than with Slovenia. Even though we can see clear bias towards right-wing authoritarian politics and an almost empty left-authoritarian quadrant, it is definitely interesting that interest groups tend to be more evenly distributed than Polish and Lithuanian parties, particularly in the right-wing economic and Gal quadrant. The difference between these two countries lies in the extreme position. While in Lithuania, there are many such groups, in Poland there are only

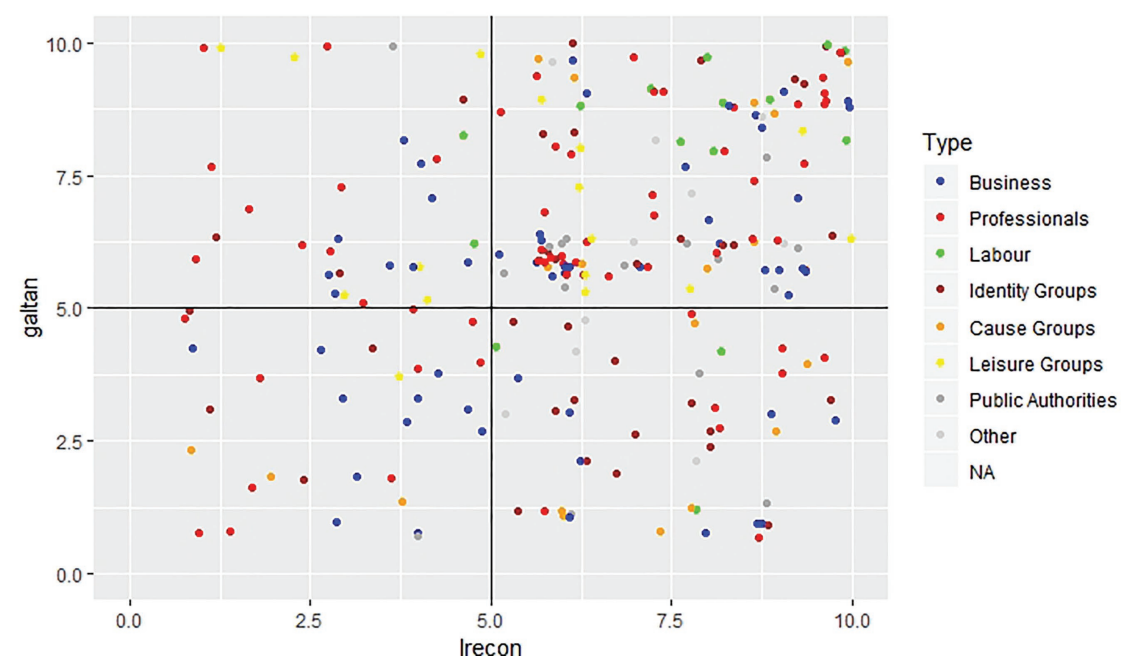

FIGURE 12.2 Gal-Tan and economic left-right self-placement of interest groups in Lithuania.

Source: CIGS. 
few. Regarding which types of groups "fill the blanks", the case of Lithuania is quite representative. However, they are mostly trade unions, business groups, and professional associations. In Poland though, the outmost positions in the upper-right corner are filled by cause groups and business associations.

By contrast, Slovenian interest groups appear to be more left-leaning, culturally often self-placed in extreme areas, where hardly any Lithuanian and Polish groups were to be found and with sparsely populated right-authoritarian areas.

The divergence between Slovenia and other countries in the region is striking and lays ground for further research how interest organizations emerge to "satisfy" the demand for certain types of representation among citizens. It is also safe to say that Slovenian interest organizations do not compensate for political parties in the above-mentioned gap in the upper-right quadrant. Interestingly, in the Slovenian case, we have plenty of groups presenting extreme positions in the lower-left corner, which means the highest support for state's reduced role in economic matters as well as libertarian point of view of cultural issues. In view of the neo-corporatist tradition of the Slovenian state, the further analysis should focus on whether interest groups represent a neo-liberal counter-movement. What would support this hypothesis is the type of groups - a handful of associations of professionals, business, and cause groups.

Apart from Slovenia, we see dozens of groups populating spaces left by political parties. Particularly interesting is the large number of such groups in Sweden, Belgium, and the Netherlands. The disillusionment with market politics after the Euro-crisis could be one factor. However, the shift towards the center-right

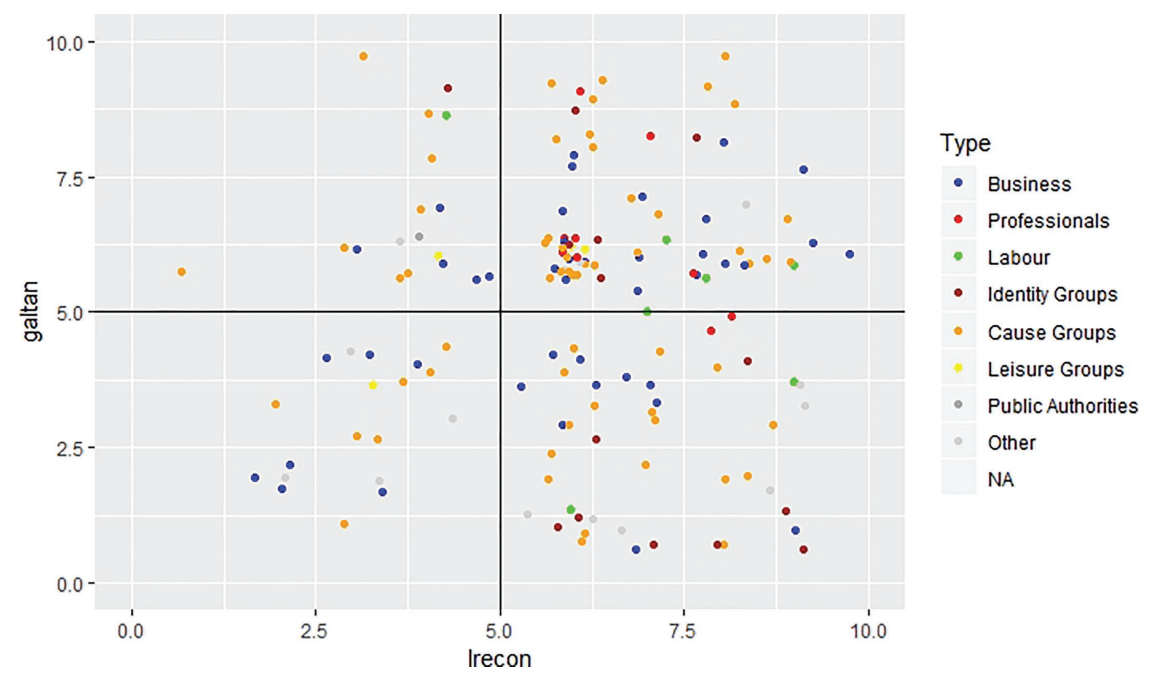

FIGURE 12.3 Gal-Tan and economic left-right self-placement of interest groups in Poland.

Source: CIGS. 


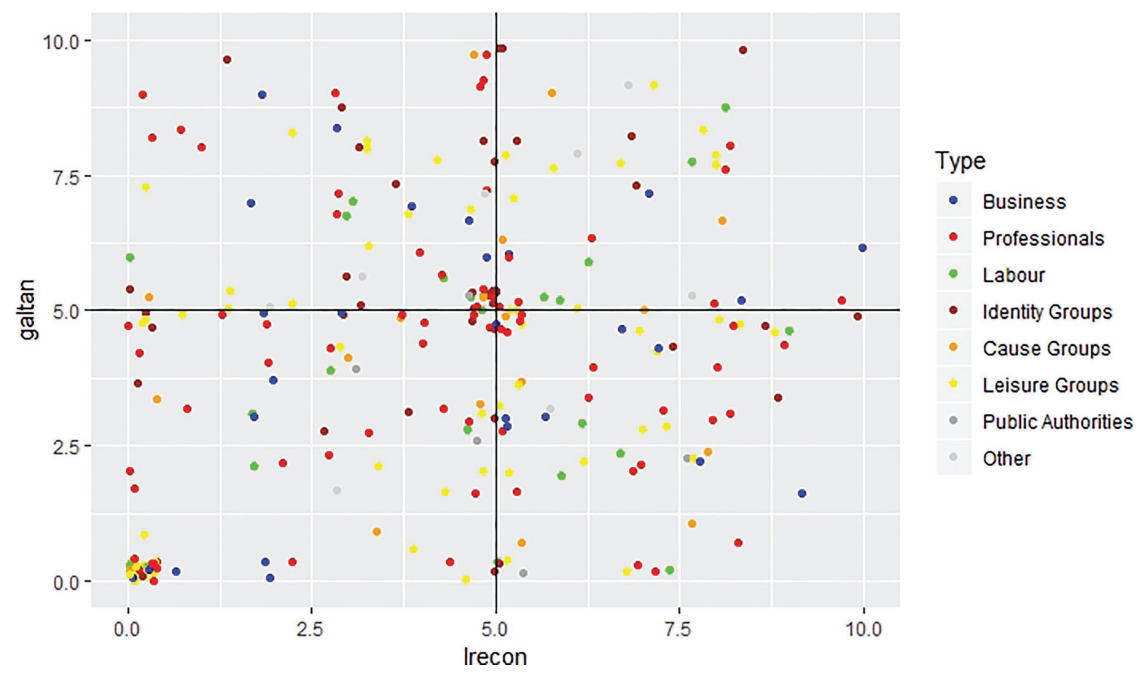

FIGURE 12.4 Gal-Tan and economic left-right self-placement of interest groups in Slovenia.

Source: CIGS.

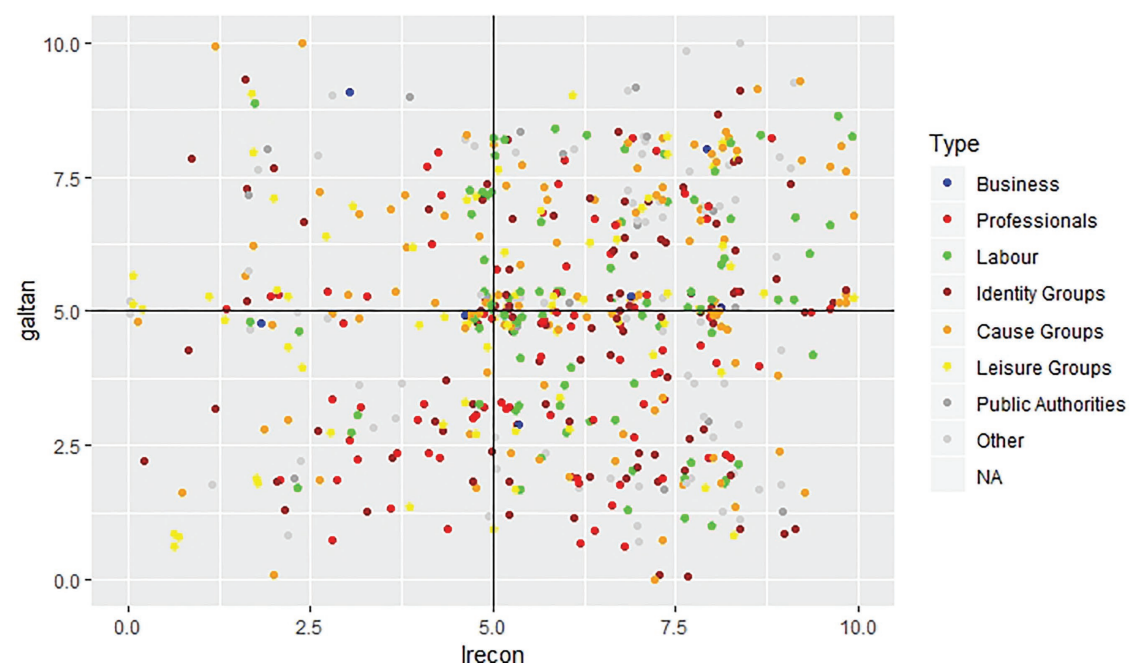

FIGURE 12.5 Gal-Tan and economic left-right self-placement of interest groups in the Netherlands.

Source: CIGS.

"traditional" space is another issue and begs for further investigation, accounting for cross-national surveys of populations as well.

In terms of what types of groups fill the spaces left by political parties, we do not see any dominating trend. In the Netherlands, these spaces are dominated 
mostly by trade unions and cause groups. In Sweden business groups and some cause and identity groups spilled over to the "more active role of the state" half, but are not entirely in Tan areas. In Belgium, we have the most representative case where a myriad of different organizations occupy areas left by political parties.

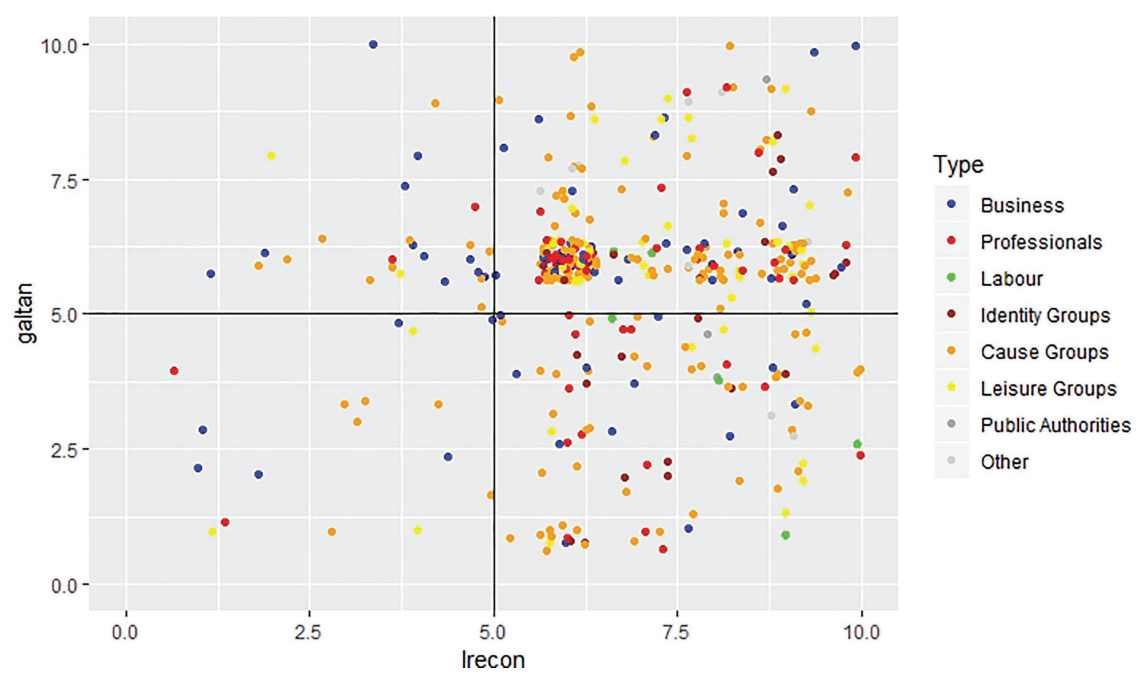

FIGURE 12.6 Gal-Tan and economic left-right self-placement of interest groups in Sweden.

Source: CIGS.

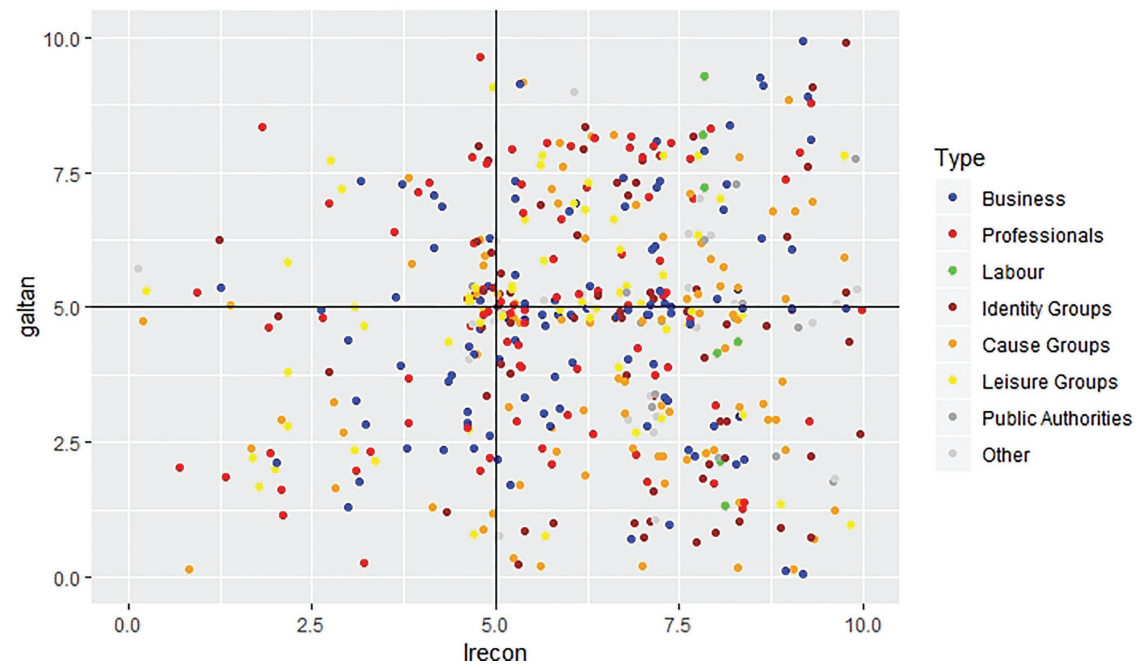

FIGURE 12.7 Gal-Tan and economic left-right self-placement of interest groups in Belgium.

Source: CIGS. 


\section{Conclusions}

The goal of this chapter was to analyze the propensity with which interest groups populate two-dimensional ideological spaces left by political parties. I used the Chapel Hill Expert Survey as well as novel data from a multinational interest group survey project to investigate six EU countries representing the east and west of the continent. The CHES data allowed us to identify the gap, which could be seen in the upper-right quadrant, suggesting a shortage of representation of voters strongly supporting an active role of the state with a traditional and nationalist cultural agenda. By analyzing the interest group survey data, I found out that in five of six countries, there are groups that could potentially compensate for the absence of political parties. This does not necessarily suggest causal inference, where voters are - firstly - aware of the existence of organizations representing their points of view. Secondly, even though they could have been aware of their existence, it does not mean that there are no other factors in play here that would make citizens reluctant to rely more on interest organizations than on political parties, even though the latter are not congruent with their beliefs.

The fundamental question - whether groups can compensate for political parties - boils down to being able to influence public policy processes and therefore satisfy needs of groups' constituencies. As the gap is somewhere between culturally right-wing (Tan) and economically redistributive policies, the impact of groups might be rather limited, but again to assess that, further research is needed.

Secondly, it is worth asking whether interest groups themselves would like to compensate for political parties. There is some evidence that groups face similar internal and external challenges, particularly involving their membership base, funding, and growing professionalization during their evolution from grass-root movements.

Interest groups appear to cover a wider range of ideological spaces than political parties. This pattern allows us to be wary of region-specific generalizations as there is very much variability in the dynamic relations between political parties and interest groups in CEE. Furthermore, interest groups follow - more or less - country-specific patterns. If we see political parties dominating certain ideological areas, the same is likely to happen with interest groups, for example the left-Gal combination in Slovenia and clear right-authoritarian bias in Poland.

Due to the greater supply of interest groups than political parties, citizens could find atypical combinations that suit them. The fundamental question - and material for further analysis - is whether citizens really look for party alternatives and whether interest organizations seek the vast support of citizens. It would be fascinating to combine the current research with a bottom-up approach and use cross-country data from the European Social Survey to thoroughly investigate the supply and demand dynamics of voters' representation. The bottom line is that in five of six countries, some interest groups are where political parties are 
not. Sounding like a truism, associative democracy is vital for the health and stability of representative and democratic governments.

\section{Note}

1 See http://www.cigsurvey.eu/. As for today (mid-2020) the project includes Belgium, Lithuania, Poland, the Netherlands, Sweden, Slovenia, Italy, and Spain. Data are currently being collected for Montenegro, the Czech Republic and Portugal.

\section{References}

Allern, E. H. (2010). Political parties and interest groups in Norway. Colchester: ECPR Press.

Allern, E. H., \& Bale, T. (2012). Political parties and interest groups: Disentangling complex relationships. Party Politics, 18(1), 7-25. doi: 10.1177/1354068811422639.

Allern, E. H., \& Bale, T. (Eds.). (2017). Left-of-centre parties and trade unions in the twentyfirst century. Oxford: Oxford University Press.

Berkhout, J., Hanegraaff, M., \& Statsch, P. (2020). Interest groups in multi-level contexts: European integration as cross-cutting issue in party-interest group contacts. Politics and Governance, 8(1), 61-71. doi: 10.17645/pag.v8i1.2516.

Beyers, J., Bernhagen, P., Borang, F., Braun, C., Fink-Hafner, D., Heylen, F., Maloney, W., Naurin, D., \& Pakull, D. (2016). Comparative interest group survey questionnaire. Antwerp: University of Antwerp.

Beyers, J., Eising R., \& Maloney, W. (2008). Researching interest group politics in Europe and elsewhere: Much we study, little we know?. West European Politics, 31(6), 1103-1128. doi: 10.1080/01402380802370443.

Bohle, D., \& Greskovits, B. (2012). Capitalist diversity on Europe's periphery. Ithaca, NY: Cornell University Press.

Bornschier, S. (2010). Cleavage politics and the populist right. The new cultural conflict in Western Europe. Philadelphia, PA: Temple University Press.

Bevan, S., \& Rasmussen, A. (2020). When does government listen to the public? Voluntary associations and dynamic agenda representation in the United States. Policy Studies Journal, 48(1), 111-132. doi: 10.1111/psj.12231.

Binderkrantz, A. S., \& Christiansen, P. M. (2015). From classic to modern corporatism. Interest group representation in Danish public committees in 1975 and 2010. Journal of European Public Policy, 22(7), 1022-1039. doi: 10.1080/13501763.2014.1000365.

Bolleyer, N. (2009). Inside the cartel party: Party organisation in government and opposition. Political Studies, 57(3), 559-579. doi: 10.1111/j.1467-9248.2008.00741.x.

Borang, F., Naurin D., \& Polk J. (2017). Making space. A cross-country comparison of parties and interest groups positioning in multiple policy dimensions. Conference paper presented at ECPR General Conference in 2017.

Bornschier, S. (2010). The new cultural divide and the two-dimensional political space in Western Europe. West European Politics, 33(3), 419-444. doi: 10.1080/01402381003654387.

Bunce, V. (1995). Should transitologists be grounded?. Slavic Review, 54(1), 111-127.

Burstein, P., \& Linton, A. (2002). The impact of political parties, interest groups, and social movement organizations on public policy: Some recent evidence and theoretical concerns. Social forces, 81(2), 380-408. doi: 10.1353/sof.2003.0004.

Casal Bértoa, F., \& Spirova, M. (2019). Parties between thresholds: State subsidies and party behaviour in post-communist democracies. Party Politics, 25(2), 233-244. 
Christiansen, P. M., Mach, A., \& Varone, F. (2018). How corporatist institutions shape the access of citizen groups to policy-makers: Evidence from Denmark and Switzerland. Journal of European Public Policy, 25(4), 526-545. doi: 10.1080/13501763.2016.1268194.

Coman, E. (2017). Dimensions of political conflict in West and East: An application of vote scaling to 22 European parliaments. Party Politics, 23(3), 248-261. doi: $10.1177 / 1354068815593454$.

Crawford, B., \& Lijphart, A. (1995). Explaining political and economic change in post-communist Eastern Europe: Old legacies, new institutions, hegemonic norms, and international pressures. Comparative Political Studies, 28(2), 171-199. doi: 10.1177/0010414095028002001.

Dalton, R. J., Farrell, D. M., \& McAllister, I. (2011). Political parties and democratic linkage: How parties organize democracy. Oxford: Oxford University Press.

Dobbins, M., \& Riedel, R. (2018). The new research agenda of examining organized interests in post-communist policy-making. Rocznik Instytutu Europy ŚrodkowoWschodniej, 16(5), 61-79.

Easton, D. (1971). Political system. An inquiry into the state of political science. New York: Alfred A. Knopf.

Eising, R. (2008). Clientelism, committees, pluralism and protests in the European Union: Matching patterns?. West European Politics, 31(6), 1166-1187. doi: 10.1080/01402380802372647.

Elster, J., Offe, C., Preuss, U. K., Boenker, F., Goetting, U., \& Rueb, F. W. (1998). Institutional design in post-communist societies: Rebuilding the ship at sea. Cambridge: Cambridge University Press.

Enyedi, Z. 2006. Party politics in post-communist transition. In R. S.Katz \& W. Crotty (Eds.), Handbook of Party Politics (pp. 228-238). London: Sage. Fink-Hafner, D. (2011). Interest representation and post-communist parliaments over two decades. The Journal of Legislative Studies, 17(2), 215-233. doi: 10.1080/13572334.2011.574027.

Fraussen, B., \& Beyers, J. (2016). Who's in and who's out?: Explaining access to policymakers in Belgium. Acta Politica, 51(2), 214-236. doi: 10.1057/ap.2015.9.

Fraussen, B., \& Halpin, D. R. (2018). Political parties and interest organizations at the crossroads: Perspectives on the transformation of political organizations. Political Studies Review, 16(1), 25-37. doi: 10.1177/1478929916644868.

Gilens, M. (2012). Two-thirds full? Citizen competence and democratic governance. In Berinsky, A (Ed), New directions in public opinion (pp. 65-89). London: Routledge.

Grant, W. (2001). Pressure politics: From 'insider'politics to direct action?. Parliamentary Affairs, 54(2), 337-348. doi: 10.1093/parlij/54.2.337.

Hanley, S., \& Sikk, A. (2016). Economy, corruption or floating voters? Explaining the breakthroughs of anti-establishment reform parties in eastern Europe. Party Politics, 22(4), 522-533. doi: 10.1177/1354068814550438.

Hasenfeld, Y., \& Gidron, B. (2005). Understanding multi-purpose hybrid voluntary organizations: The contributions of theories on civil society, social movements and non-profit organizations. Journal of Civil Society, 1(2), 97-112. doi: 10.1080/17448680500337350.

Hassel, A. (2008). The evolution of a global labor governance regime. Governance, 21(2), 231-251.

Haughton, T. (2014). Money, margins and the motors of politics: The EU and the development of party politics in Central and Eastern Europe. Journal of Common Market Studies, 52(1), 71-87. doi: 10.1111/jcms.12080. 
Häusermann, S., \& Geering, D. (2011). Policy congruence and distributive politics: Matching voter preferences and party positions on labor market policy. In APSA 2011 Annual Meeting Paper.

Heaney, M. T. (2010). Linking political parties and interest groups. In L. S. Maisel \& J. M. Berry (Eds.), The Oxford handbook of American political parties and interest groups. Oxford: Oxford University Press.

Hojnacki, M., \& Kimball, D. C. (1998). Organized interests and the decision of whom to lobby in Congress. American Political Science Review, 92(4), 775-790. doi: $10.2307 / 2586303$.

Hooghe, L., Marks, G., \& Wilson, C. J. (2002). Does left/right structure party positions on European integration? Comparative Political Studies, 35(8), 965-989. doi: 10.1177/001041402236310.

Howard, M. M. (2003). The weakness of civil society in post-communist Europe. Cambridge: Cambridge University Press.

Katz, R. S., \& Mair, P. (1995). Changing models of party organization and party democracy: The emergence of the Cartel party. Party Politics, 1(1):5-28. doi: $10.1177 / 1354068895001001001$.

Katz, R. S., \& Mair, P. (2009). The cartel party thesis: A restatement. Perspectives on Politics, 7(4), 753-766.

Katz, R. S., \& Mair, P. (2012). Parties, interest groups and cartels: A comment. Party Politics, 18(1), 107-111. doi: 10.1177/1354068811422644.

Kitschelt, H., Mansfeldova, Z., Markowski, R., \& Toka, G. (1999). Post-communist party systems: Competition, representation, and inter-party cooperation. Cambridge: Cambridge University Press.

Krašovec, A., \& Haughton, T. (2011). Money, organization and the state: The partial cartelization of party politics in Slovenia. Communist and Post-Communist Studies, 44(3), 199-209. doi: 10.1016/j.postcomstud.2011.07.003.

Lefkofridi, Z., Wagner, M., \& Willmann, J.E. (2014). Left-authoritarians and policy representation in Western Europe: Electoral choice across ideological dimensions. West European Politics, 37(1), 65-90. doi: 10.1080/01402382.2013.818354.

Mair, P. (1997). Party system change: Approaches and interpretations. Oxford: Oxford University Press.

Offe, C., \& Adler, P. (1991). Capitalism by democratic design? Democratic theory facing the triple transition in East Central Europe. Social Research, 58(4), 865-892.

Otjes, S., \& Rasmussen, A. (2017). The collaboration between interest groups and political parties in multi-party democracies: Party system dynamics and the effect of power and ideology. Party Politics, 23(2), 96-109. doi: 10.1177/1354068814568046.

Poguntke, T. (1996). Anti-party sentiment-Conceptual thoughts and empirical evidence: Explorations into a minefield. European Journal of Political Research, 29(3), 319-344. doi: 10.1111/j.1475-6765.1996.tb00655.x.

Polk, J., Rovny, J., Bakker, R., Edwards, E., Hooghe, L., Jolly, S., \& Steenbergen, M. (2017). Explaining the salience of anti-elitism and reducing political corruption for political parties in Europe with the 2014 Chapel Hill Expert Survey data. Research E Politics, 4(1). doi: 10.1177/2053168016686915.

Putnam, R.D. (1993). The prosperous community. Am. Prospect 4 (13), 35-42.

Putnam, R. D. (1995). Tuning in, tuning out: The strange disappearance of social capital in America. PS: Political Science \& Politics, 28(4), 664-684. 
Rasmussen, A., Carroll, B. J., \& Lowery, D. (2014). Representatives of the public? Public opinion and interest group activity. European Journal of Political Research, 53(2), 250-268.

Rohrschneider, R., \& Whitefield, S. (2012). The strain of representation: How parties represent diverse voters in Western and Eastern Europe. Oxford: Oxford University Press.

Sartori, G. (1976). Parties and party systems. A framework for analysis. London: Cambridge University Press.

Sata, R., \& Karolewski, I. P. (2020). Caesarean politics in Hungary and Poland. East European Politics, 36(2), 206-225. doi: 10.1080/21599165.2019.1703694.

Sikk, A. (2003). A Cartel party system in a post-communist country? The case of Estonia. Paper presented at ECPR General Conference, 18-21 September 2003, Marburg, Germany.

Skocpol, T. (2003). Diminished democracy. Norman: Oklohoma University Press.

Szczerbiak, A. (2001). Cartelisation in post-communist politics: State party funding in post-1989 Poland. Perspectives on European Politics and Society, 2(3), 431-451. doi: 10.1080/1570585018458771.

Thomas, C. S. (2001). Political parties and interest groups: Shaping democratic governance. Boulder, CO: Lynne Rienner.

Truman, D. B. (1993). The governmental process: Political interests and public opinion. Berkley, CA: Institute of Governmental Studies.

Vachudova, M. A., \& Hooghe, L. (2009). Postcommunist politics in a magnetic field: How transition and EU accession structure party competition on European integration. Comparative European Politics, 7(2), 179-212. doi: 10.1057/cep.2008.9.

Van Biezen, I. (2003). Political parties in new democracies: Party organization in Southern and East-Central Europe. London: Palgrave Macmillan.

Van Biezen, I., Mair, P., \& Poguntke, T. (2012). Going, going,... gone? The decline of party membership in contemporary Europe. European Journal of Political Research, 51(1), 24-56. doi: 10.1111/j.1475-6765.2011.01995.x.

Wheatley, J., \& Mendez, F. (2019). Reconceptualizing dimensions of political competition in Europe: A demand-side approach. British Journal of Political Science, 1-20. doi: 10.1017/s0007123418000571.

Witko, C. (2009). The ecology of party-organized interest relationships. Polity, 41(2), 211-234. doi: 10.1057/pol.2008.30.

Yishai, Y. (1998). Civil society in transition: Interest politics in Israel. The Annals of the American Academy of Political and Social Science, 555(1), 147-162. 